\title{
COMPARATIVE BIOLOGY OF TWO POPULATIONS OF Lutzomyia umbratilis (DIPTERA: PSYCHODIDAE) OF CENTRAL AMAZONIA, BRAZIL, UNDER LABORATORY CONDITIONS
}

\author{
JUSTINIANO, S. C. B., CHAGAS, A. C., PESSOA, F. A. C. and QUEIROZ, R. G. \\ Instituto Nacional de Pesquisas da Amazônia, INPA/CPCS, C.P. 478, CEP 69011-970, Manaus, AM, Brazil \\ Correspondence to: Raul G. Queiroz, Instituto Nacional de Pesquisas da Amazônia, INPA/CPCS, C.P. 478, \\ CEP 69011-970, Manaus, AM, Brazil, e-mail: raul@inpa.gov.br \\ Received November 19, 2002 - Accepted March 25, 2003 - Distributed May 31, 2004
}

(With 3 figures)

\begin{abstract}
Lutzomyia umbratilis is the main vector of cutaneous leishmaniasis due to Leishmania guyanensis in northern South America. It has been found naturally infected with this species of Leishmania only east of the Rio Negro and north of the Rio Amazonas. However, populations of this sand fly species are also present in areas south of the Amazon river system, which may act as a geographical barrier to the Leishmania guyanensis cycle. With the aim of looking for possible biological differences between populations of $L$. umbratilis from each side of this river system, their biology in the laboratory was investigated. Progenitors collected on tree bases in Manaus and Manacapuru (east and west, respectively, of the Rio Negro) were reared in the laboratory. Results from observations of the life cycle, fecundity, fertility, and adult longevity at $27^{\circ} \mathrm{C}$ and $92 \% \mathrm{RH}$ were analyzed by descriptive statistics and $\mathrm{z}, \mathrm{t}, \mathrm{U}$, and $\chi^{2}$ tests. Although the Manaus and Manacapuru colonies showed a longer developmental time than most Lutzomyia species reared at similar temperatures, length of time of egg and $4^{\text {th }}$ instar larva of the two populations differed significantly ( $p<0.01)$. Females of the latter retained significantly $(\mathrm{p}<0.001)$ less mature oocytes, and the general productivity (\% adults from a known number of eggs) of the colony was significantly $(\mathrm{p}<0.01)$ higher than that of the former. These results show that the L. umbratilis population of Manaus is more productive, and thus a better candidate for future mass-rearing attempts. The two populations differ in their life cycle, fecundity, fertility, adult longevity, and emergence. These differences may reflect some divergence of intrinsic biological features evolved as a result of their geographical isolation by the Rio Negro. It is expected that further investigations on morphometry, cuticular hydrocarbon, isoenzyme, molecular and chromossomal analyses, infection, and cross-mating experiments with these and other allopatric populations of both margins of the Amazon river system will help reveal whether or not $L$. umbratilis has genetically diverged into two or more reproductively isolated populations of vectors or non-vectors of Leishmania guyanensis.
\end{abstract}

Key words: Lutzomyia umbratilis, laboratory-rearing, phlebotomine sand fly vector, cutaneous leishmaniasis.

\section{RESUMO}

\section{Biologia comparada de duas populações de Lutzomyia umbratilis (Diptera: Psychodidae) da Amazônia Central, Brasil, sob condições de laboratório}

Lutzomyia umbratilis é o principal vetor de leishmaniose tegumentar causada por Leishmania guyanensis no norte da América do Sul. Essa espécie tem sido encontrada naturalmente infectada com Leishmania somente ao leste do Rio Negro e norte do Rio Amazonas. Porém, populações dessa espécie de flebotomíneo também estão presentes em áreas do sul do sistema fluvial do Rio Amazonas, o qual pode atuar como uma barreira geográfica no ciclo da Leishmania guyanensis. Com o objetivo de procurar possíveis 
diferenças biológicas entre populações de L. umbratilis de margens opostas desse sistema fluvial, a biologia de duas populações diferentes foi estudada em laboratório. Progenitores coletados em Manaus e Manacapuru (leste e oeste, respectivamente, do Rio Negro) foram criados separadamente. Resultados de observações do ciclo de vida, fecundidade, fertilidade e longevidade de adultos a $27^{\circ} \mathrm{C}$ e $92 \%$ UR (umidade relativa) foram analisados por estatística descritiva, e testes z, t, $\mathrm{U}$ e $\chi^{2}$. Embora as colônias de Manaus e Manacapuru tenham apresentado desenvolvimento mais demorado que a maioria das espécies de Lutzomyia, a duração das fases de ovo e de larva de 4o estágio nas duas populações foi significativamente $(\mathrm{p}<0,01)$ diferente. Fêmeas de Manaus retiveram significativamente $(\mathrm{p}<0.001)$ menos óvulos maduros, e a produtividade geral (\% de adultos a partir de um número conhecido de ovos) da colônia foi significativamente $(\mathrm{p}<0,01)$ mais alta do que a de Manacapuru. Estes resultados apontam a população de L. umbratilis de Manaus como a melhor candidata a futuras tentativas de criação em massa em laboratório. As diferenças observadas nas duas populações quanto ao ciclo de vida, fecundidade, fertilidade, longevidade e emergência de adultos podem ser resultantes do isolamento geográfico ocasionado pelos grandes rios.

Palavras-chave: Lutzomyia umbratilis, criação em laboratório, flebotomíneo vetor, leishmaniose tegumentar.

\section{INTRODUCTION}

Lutzomyia umbratilis is the main vector of cutaneous leishmaniasis due to Leishmania guyanensis (Kinetoplastida: Trypanosomatidae) in northern South America. Its vectorial role has been demonstrated as a result of epidemiological studies in the Brazilian State of Pará, Eastern Amazonia (Lainson et al., 1976; Lainson et al., 1979; Lainson et al., 1981) and Amazonas, Central Amazonia (Arias \& Freitas, 1977; Arias \& Freitas, 1978; Arias \& Naiff, 1981), and in French Guiana (Le Pont \& Pajot, 1980; Gentile et al., 1981; Pajot et al., 1982). L. umbratilis has also been reported to occur in other areas within the Amazon rain forest range (Young \& Duncan, 1994) and in remnants of the Brazilian Atlantic rain forest (Balbino et al., 2001), where its local role as a vector of leishmaniasis is still undetermined.

In the State of Amazonas, 15,000 human cases of cutaneous leishmaniasis were registered from 1992 to 2000, with the Municipality of Manaus having the highest incidence: a reported 7,000 cases (SUSAM, State of Amazonas, unpublished). Nearly all these infections are believed to be due to Leishmania guyanensis and occurred in recent human settlements close to forested areas or as a result of anthropogenic activity in the primary forest, e.g., timber harvest, hunting, fruit collecting, and mining.

L. umbratilis has been found naturally infected with Leishmania guyanensis only east of the Rio Negro and north of the Rio Amazonas, where most of the human infections are believed to have been contracted (Arias \& Freitas, 1977, 1978; Barrett, 1993). Only trypanosomatid infections other than Leishmania have been reported to occur in phlebotomine sand flies south of the Amazon river system, where populations of L. umbratilis are locally abundant (Queiroz et al., in preparation). These facts led Arias \& Freitas (1978) to suggest that this river system may act as a geographical barrier to the cycle of Leishmania guyanensis, which could be transmitted by different vectors in areas on the opposite margins.

Early attempts to compare different populations of $L$. umbratilis of areas within the geographical range of Leishmania guyanensis demonstrated morphological similarities between French Guyana and Monte Dourado (Brazil) populations (Ward \& Fraiha, 1977), and reproductive compatibility between Manaus (State of Amazonas, Brazil) and Monte Dourado (State of Pará, Brazil) populations (Ready et al., 1986). Recently, differences in quantitative morphological characters have been reported in several populations of L. umbratilis of Brazil and Venezuela (Azevedo et al., 2002). Ecological investigations have shown similar behavioural features of L. umbratilis populations of Brazil (Arias \& Freitas, 1977; Arias \& Freitas, 1982; Ready et al., 1986) and French Guiana (Le Pont, 1982).

In the light of Arias \& Freitas' hypothesis, the present work sought possible differences in the life cycle, fecundity, fertility, and adult longevity between laboratory-reared L. umbratilis of two populations separated by the Rio Negro. 


\section{MATERIAL AND METHODS}

Female progenitors were collected in the following areas of terra firme (non-flooded) forest in the State of Amazonas: (i) Urbano Manuel Road (AM070), km 70, (03¹0'S/60³0'W), Municipality of Manacapuru; and (ii) Vivenda Verde District $\left(03^{\circ} 08^{\prime} 01 \mathrm{~S} / 60^{\circ} 18^{\prime} 34 \mathrm{~W}\right)$, Municipality of Manaus (Fig. 1).

Resting sand flies were caught in the daytime by sweeping around tree bases with a CDC miniature light-trap (Hausherr's Machine Works, New Jersey, USA) used as a mechanical aspirator. Sand fly laboratory-rearing followed the methods described by Killick-Kendrick et al. (1977), KillickKendrick (1987), and Killick-Kendrick \& Killick-Kendrick (1991). Briefly, caged gravid wild females were caught individually in glass vials for oviposition, and unengorded females were offered a bloodmeal on hamster previously anesthetized with Thionembutal ${ }^{\circledR}$. They were maintained in cages with sucrose solution $(1: 1, \mathrm{v} / \mathrm{v})$ until ovariole development was completed, and then individualized as above. After oviposition and death, females were identified according to Young \& Duncan (1994). The eggs were counted, and transferred to plaster-lined Nalgene $\mathrm{T}^{\mathrm{TM}}$ pots $(60 \mathrm{ml})$, which were maintained in closed plastic boxes whose bottoms were filled with dampened sand. To prevent $1^{\text {st }}$ and $2^{\text {nd }}$ instar larvae from escaping, a very fine nylon fabric was used to close the top of the pot. Larvae fed on a mixture $(1: 1, \mathrm{v} / \mathrm{v})$ of ground forest litter and aquarium fish food (dehydrated earthworm) (Tetra Delica $\left.{ }^{\circledR}\right)$. Colonies were maintained at $27^{\circ} \mathrm{C}, 92 \%$ relative humidity (RH), and light:dark cycle of LD 12:12.

For the comparison between the populations of L. umbratilis of Manacapuru and Manaus, the following parameters were considered:

\section{Life cycle}

Each rearing pot was divided into four compartments of same size. Thirty $F_{1}$ eggs (from a pool of eggs of same age) and a small amount of larval food were deposited in one compartment of each pot. To determine the period of time of each instar, larvae were transferred from one compartment to the following (in a clockwise direction) just after eclosion or moulting. Three replicates of 3 pots with 30 eggs in each (total $=270$ eggs) were used for each population.

\section{Longevity of adults}

Sixteen $\mathrm{F}_{1}$ flies (eight males and eight females) were maintained in a cage with a slice of apple as the only source of sugar. As a control, the same number of males and females were kept in another cage with a little cotton wool soaked in distilled water. Two replicates of two cages (apple and control) were used for each population and observations were made daily for the number of dead males and females.

\section{Fecundity of wild females}

The fecundity of a single female was calculated by counting the number of mature oocytes retained in the ovarioles (after death) and those actually laid. Three sets of 30 wild females of each population were used, and the data were analysed by z-test (Fowler \& Cohen, 1990).

\section{Fertility of $F_{1}$ eggs and number of adults originated from a known number of eggs}

Sixty $F_{1}$ eggs (from a pool of eggs of the same age) were deposited in each pot and reared to adults. Two replicates of 3 pots each (total $=360$ eggs) were used for each population and the observations were made daily of the number of ecloding larvae or newly-emerged adults. The numbers of females and males emerged per day were compared by the MannWhitney U-test (Fowler \& Cohen, 1990).

\section{RESULTS}

\section{Life cycle}

Descriptive statistics on developmental times of the immature stages (egg, larva, and pupa) of Manaus and Manacapuru are shown in Table 1. The total length of time from egg-pupa of the two populations did not differ significantly $(t=0.826, p>0.05)$, although duration of the egg stage of the Manaus colony was significantly $(\mathrm{U}=0.000, \mathrm{p}<0.01$ MannWhitney) longer, and duration of the $4^{\text {th }}$ instar larval stage was significantly $(\mathrm{U}=0.001, \mathrm{p}<0.01$, MannWhitney) shorter, than those of Manacapuru colony.

\section{Longevity of adults}

Females of the two populations survived up to 13 days after emergence, while the males of Manacapuru lasted up to 11 days and those of Manaus, up to 10 days (Figs. 2A and 2B). The number of live flies per day of the colony of Manacapuru always exceeded those of the colony of Manaus up to the $10^{\text {th }}$ day (females) and up to the $9^{\text {th }}$ day (males). Males 
of both populations maintained with only distilled water did not survive beyond the $1^{\text {st }}$ day, while only a few females of Manacapuru survived to the $2^{\text {nd }}$ day.

\section{Fecundity of wild females}

Differences in the total numbers of eggs laid by females of Manaus and Manacapuru (Table 2) were not significant $(\mathrm{z}=0.53, \mathrm{p}=0.593$, $\mathrm{z}$-test $)$.
A significantly $(\mathrm{z}=4.73, \mathrm{p}<0.001)$ larger number of oocytes were retained in the ovarioles of females of Manacapuru. However, the total number of eggs laid by females of either population was significantly $(\mathrm{z}=3.93, \mathrm{p}<0.001 ; 7.47, \mathrm{p}<0.001)$ larger than the oocytes retained in the ovarioles. With regard to total fecundity, there was no significant difference $(\mathrm{z}=1.86, \mathrm{p}=0.063)$ between the two populations.

TABLE 1

Length of time (in days) of immature stages of Lutzomyia umbratilis of Manaus and Manacapuru, State of Amazonas, Brazil.

\begin{tabular}{|c|c|c|c|c|c|c|c|c|c|c|}
\hline \multirow{2}{*}{ Stage } & \multicolumn{9}{|c|}{ Population } \\
\cline { 2 - 12 } & \multicolumn{9}{|c|}{ Manaus } & \multicolumn{6}{c|}{ Manacapuru } \\
\cline { 2 - 12 } & Min & Max & Mean & SD & N & Min & Max & Mean & SD & N \\
\hline Egg & 11 & 20 & $14.46^{\mathrm{A}}$ & 2.67 & 175 & 9 & 16 & $12.07^{\mathrm{B}}$ & 1.85 & 210 \\
\hline Larva I & 6 & 14 & $9.07^{\mathrm{A}}$ & 2.46 & 92 & 5 & 13 & $9.02^{\mathrm{A}}$ & 2.18 & 89 \\
\hline Larva II & 6 & 14 & $8.08^{\mathrm{A}}$ & 1.88 & 84 & 4 & 14 & $8.37^{\mathrm{A}}$ & 2.26 & 111 \\
\hline Larva III & 4 & 17 & $9.68^{\mathrm{A}}$ & 3.29 & 95 & 3 & 23 & $11.12^{\mathrm{A}}$ & 4.70 & 137 \\
\hline Larva IV & 8 & 27 & $15.38^{\mathrm{A}}$ & 3.72 & 101 & 9 & 30 & $18.47^{\mathrm{B}}$ & 5.14 & 97 \\
\hline Pupa & 8 & 31 & $18.47^{\mathrm{A}}$ & 5.82 & 76 & 7 & 41 & $19.61^{\mathrm{A}}$ & 8.02 & 116 \\
\hline Total & - & - & 75.14 & - & - & - & - & 78.66 & - & - \\
\hline
\end{tabular}

Uppercase = comparison between populations.

Different letters $=$ significantly different $($ Mann-Whitney $)(\mathrm{p}<0.01)$.
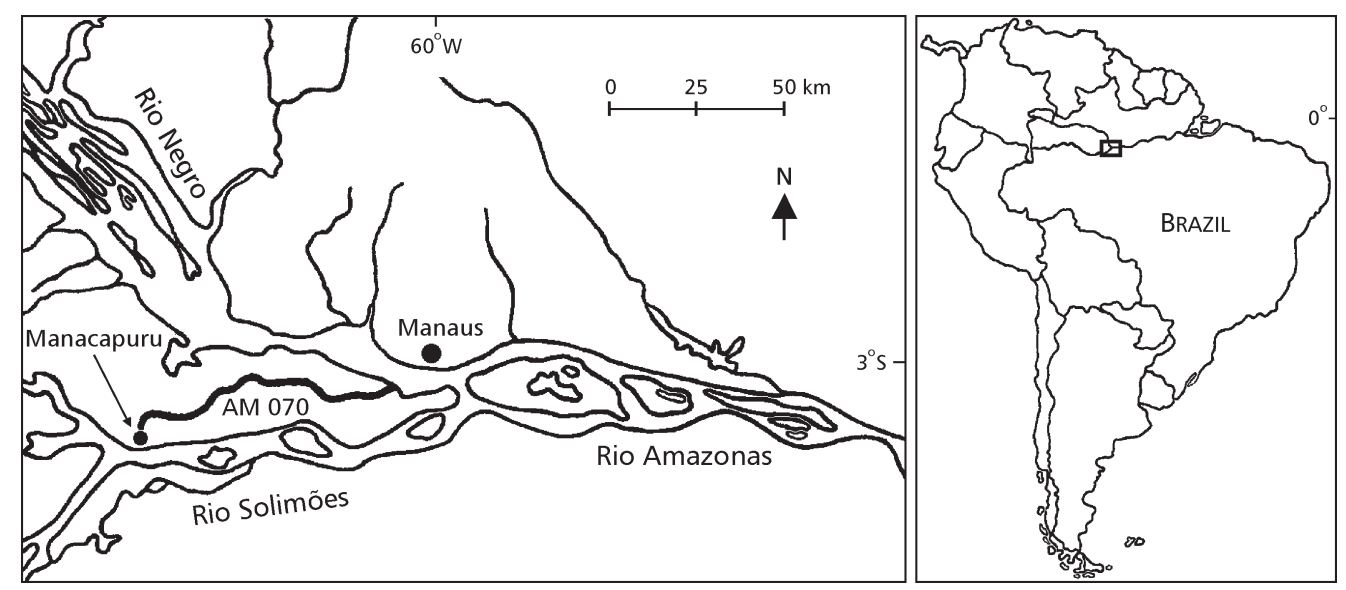

Fig. 1 - Map of the area of the confluence of Rio Negro and Rio Solimões showing the geographical position of Manaus and Manacapuru, State of Amazonas, Brazil. The location of this area in South America is shown in the map on the right. 
(A)

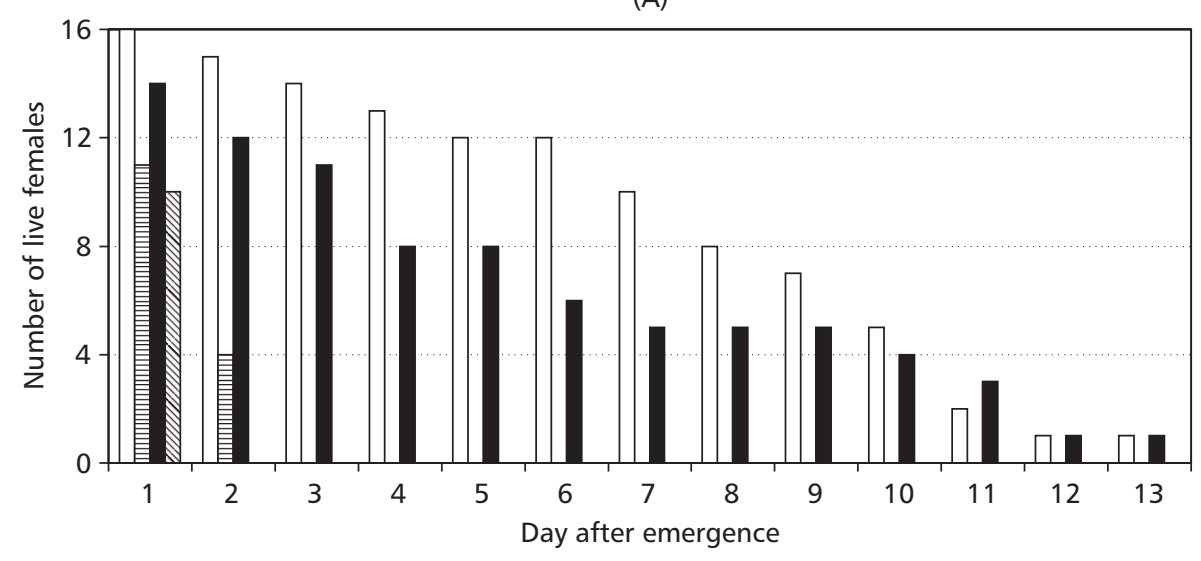

(B)

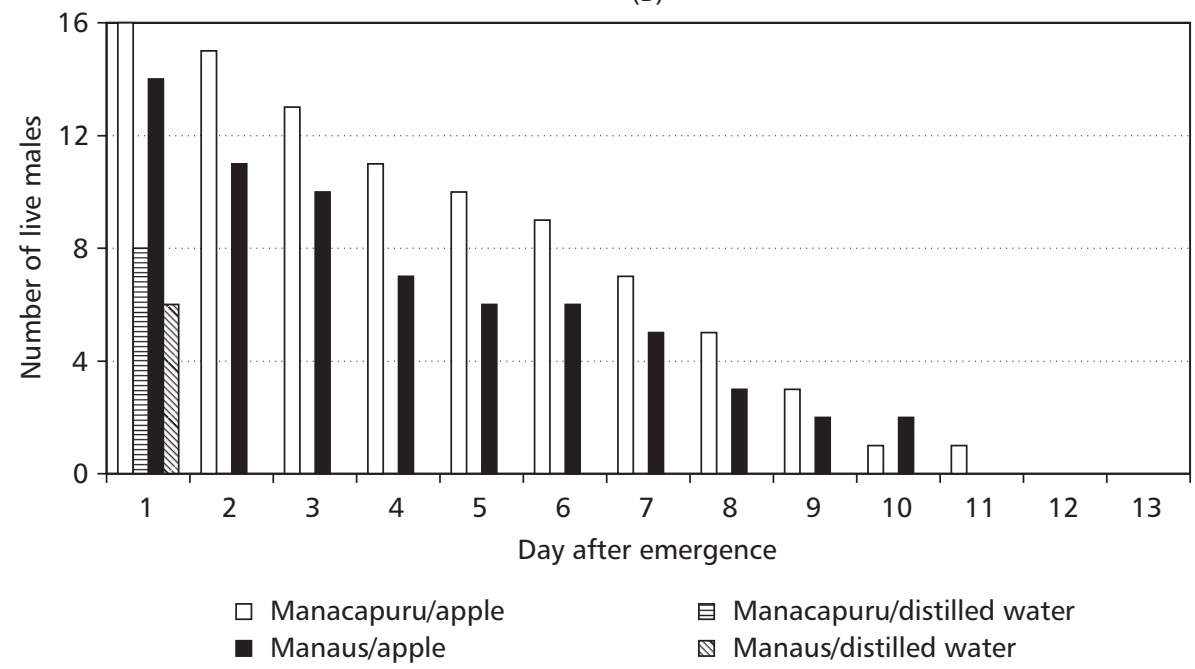

Fig. 2 - Longevity of Lutzomyia umbratilis females (A) and males (B) of Manacapuru and Manaus, State of Amazonas, Brazil.

\section{Fertility of $F_{1}$ eggs and number of adults emerged} Of a total of 360 eggs of each population, 277 $(77 \%)$ and $280(77.7 \%)$ larvae hatched from the colonies of Manaus and Manacapuru, respectively. The length of time from the eclosion of the first to the last larva was 8 days in the colony of Manacapuru and 6 days in that of Manaus. A significantly $(\mathrm{U}=$ $724, p=0.016$, Mann-Whitney) larger number of adults emerged from the initial 360 eggs laid by the wild females of Manaus (Table 3). The sex-ratio of either population was not significantly $\left(\chi^{2}=0.36\right.$, $\mathrm{p}<0.05)$ different. Adults of Manaus emerged within 20 days, and mostly on days 7-9, thus showing a unimodal temporal distribution (Fig. 3). In contrast, the emergence of the first to the last adult in the colony of Manacapuru took up to 37 days and had a bimodal distribution, with the occurrence of a $2^{\text {nd }}$ peak after the completion of emergence in the colony of Manaus. Males and females of Manaus started to emerge on the same day, while males of Manacapuru started to emerge only from the $6^{\text {th }}$ day after the initial emergence of females.

\section{DISCUSSION}

The length of time of a sand fly life cycle may be related to several extrinsic factors (e.g. temperature, humidity, and nutrition) (Barretto, 1942; Forattini, 
1973; Killick-Kendrick, 1987). In the present work, the mean developmental time from egg to pupa of the two populations of L. umbratilis was similar, although much longer than those recorded for other neotropical species reared under rather similar conditions, e.g., L. flaviscutellata (40.5 days) (Ward, 1977); L. longipalpis (34 days) (Killick-Kendrick et al., 1977), (41.3 days) (Sherlock \& Sherlock, 1959); and L. shannoni (54.6 days) (Ferro et al., 1998). The mean duration of egg stage, $4^{\text {th }}$ larval instar, and pupa of the two L. umbratilis populations were longer than the $1^{\text {st }}, 2^{\text {nd }}$, and $3^{\text {rd }}$ larval instars as recorded for other Lutzomyia species (Forattini, 1973). The greater longevity of females over males of $L$. umbratilis corroborates previous observations in colonies of other neotropical species (Queiroz, 1995).

The apple has been used routinely in the Old World sand fly colonies, particularly when there is a notable death of males, and better results have been obtained than with sucrose solutions (M. KillickKendrick, personal communication). In the New World, apple has successfully been used for mass rearing of several sand fly species (Lawyer et al., 1991; Queiroz, 1995). The larger numbers per day of live males and females of the Manacapuru colony may suggest that flies of this population are more suitable than those of Manaus for being used in studies which normally require long-living flies (e.g. experimental infection).

As observed in other insects, oviposition in sand flies is probably influenced by physiological and environmental factors. Among the physiologic factors are the oviposition pheromones, which are related to the stimulation of oviposition (Elnaiem et al., 1991). Some physical characteristics of the surface have also been shown to stimulate egg-laying (Killick-Kendrick, 1987; Elnaiem \& Ward, 1992; Nieves, 1997).
Although there was no significant difference between Manaus and Manacapuru colonies with regards to total fecundity, a significantly larger number of retained oocytes were observed in the Manacapuru flies. This may suggest that the abiotic conditions present in the insectary have not allowed the complete maturation of the oocytes, or complete action of possible oviposition pheromones, or have not provided the proper space and surface for egg-laying. Females of Manaus seem better adapted to the artificial environment as they lay more eggs from the total mature oocytes produced per gonotrophic cycle, which compensates for their lower fecundity compared to that of Manacapuru. However, the females of the latter laid 224 more eggs than those of the former. In biological terms this may be an important fact, as those eggs can originate 112 adults, of which 32 would be potentially productive females.

The influence of the egg fertility, measured by the percentage of larval eclosion, on productivity was similar in the two colonies, although the time for complete eclosion in a single generation was longer in the Manacapuru colony. This difference may reflect an intrinsic feature, since both colonies were maintained under the same conditions.

The emergence of males prior to females, normally observed in Nematocera, may be due to a longer larval stage of the females (Forattini, 1973). If this is so, our results may suggest that the larval stage of Manacapuru females is shorter than that of males, which start to emerge six days after the females in this population. The percentage of adult emergence from a known number of eggs of the two populations was similar (50\% for Manacapuru and $65 \%$ for Manaus), but was higher than those recorded for other neotropical species, e.g., L. flaviscutellata (37\%) (Ward, 1977) and L. longipalpis (23\%) (Killick-Kendrick et al., 1977).

TABLE 2

Number of eggs laid and oocytes retained by Lutzomyia umbratilis females of Manaus and Manacapuru, State of Amazonas, Brazil.

\begin{tabular}{|c|c|c|c|}
\hline Population & Eggs laid & Oocytes retained & Total \\
\hline Manaus & $2127(78.4 \%)^{\mathrm{Aa}}$ & $586(21.6 \%)^{\mathrm{Ab}}$ & $2713^{\mathrm{A}}$ \\
\hline Manacapuru & $2351(65.2 \%)^{\mathrm{Aa}}$ & $1257(34.8 \%)^{\mathrm{Bb}}$ & $3608^{\mathrm{A}}$ \\
\hline Total & 4478 & 1843 & 6321 \\
\hline
\end{tabular}

Uppercase $=$ comparison between populations.

Lowercase $=$ comparison between number of eggs laid and number of oocytes retained.

Different letters $=$ significantly different $(z$-test $)(\mathrm{p}<0.001)$.

$\mathrm{n}=90$ (each population). 
TABLE 3

Number of newly-emerged Lutzomyia umbratilis adults of Manaus and Manacapuru, State of Amazonas, Brazil.

\begin{tabular}{|c|c|c|c|}
\hline Population & Male & Female & Total \\
\hline Manaus & 111 & 123 & $234^{\mathrm{A}}$ \\
\hline Manacapuru & 77 & 103 & $180^{\mathrm{B}}$ \\
\hline Total & 188 & 226 & 414 \\
\hline
\end{tabular}

Different letters $=$ significantly different (Mann-Whitney) $(\mathrm{p}=0.01)$.

$\mathrm{n}=360$ eggs (each population).

(A)

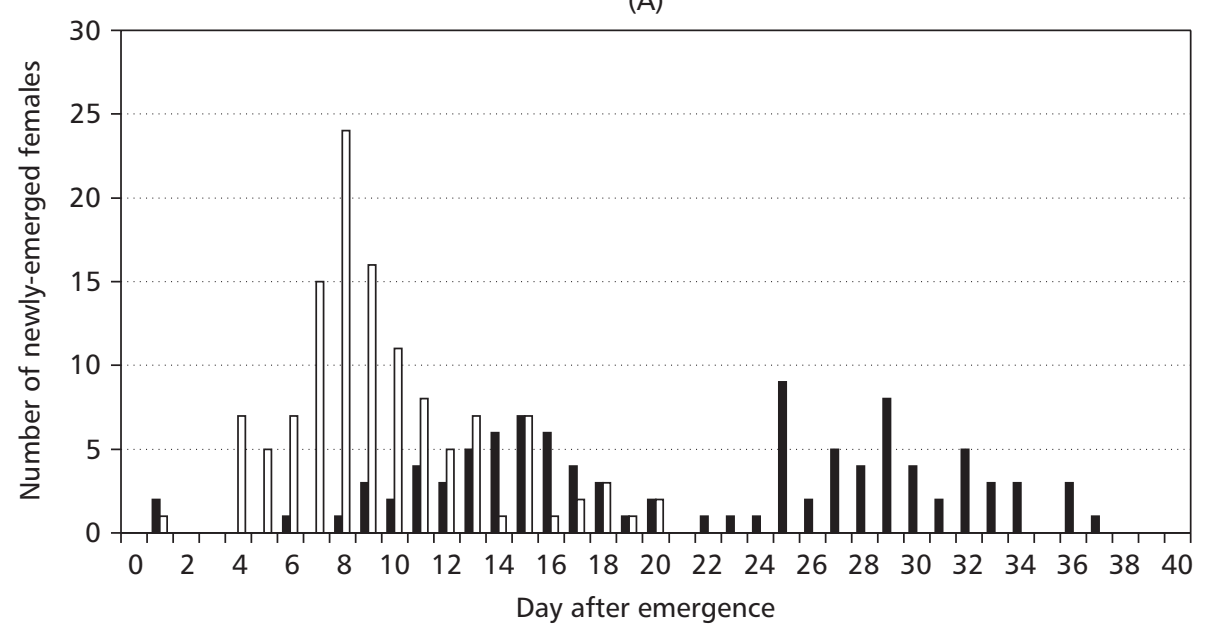

(B)

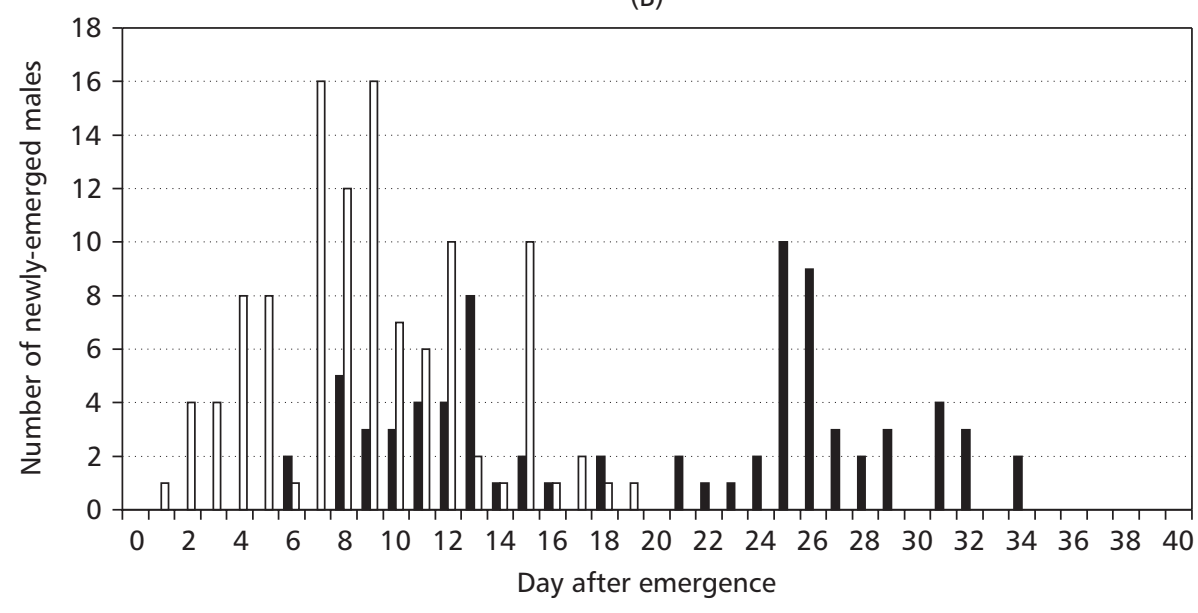

Manacapuru $\quad \square$ Manaus

Fig. 3 - Length of time of emergence of Lutzomyia umbratilis females (A) and males (B) of Manacapuru and Manaus, State of Amazonas, Brazil.

Progenitors for the establishment of the two colonies were collected in mid September, 1999, when a rapid increase in sand fly numbers followed onset of the rainy season in the collecting sites. Climatic records from 1989-1999 show that both areas have similar temperature, $\mathrm{RH}$, and rainfall 
regimes (CPRM, Ministry of Mines and Energy, Brazilian Government, unpublished). Both colonies were reared under the same conditions in the laboratory, e.g., temperature, $\mathrm{RH}$, and light:dark cycle, as an attempt to mimic those in the collecting sites. Laboratory rearing normally neglects, not only daily or annual variations of these conditions, but also a great array of biotic and abiotic environmental regulators in nature, including those in the natural breeding sites. Although is still unkinown the extent to which laboratory or natural conditions have played a role in the life histories of Manaus and Manacapuru, the differences observed in the timing of adult emergence between these colonies strongly suggest dormancy of pupae of the Manacapuru strain.

In this work, strong oocyte retention, reluctance of the larvae to feed, difficulties in bloodfeeding laboratory-reared females, and a notable tendency of the $1^{\text {st }}$ and $2^{\text {nd }}$ instar larvae to escape from the rearing pots through the top mesh, which can cause an estimated loss of up to $50 \%$ (data not shown), were the greatest difficulties in establishing $L$. umbratilis laboratory colonies. Apart from the intensive care dedicated to colony maintenance, the preparation of a special larval food, the use of apple as a sugar source for adults, and the use of very fine mesh to prevent larvae from escaping the rearing pots were important improvements and greatly contributed to the laboratory-rearing of up to three generations of L. umbratilis. Our results have shown that the population of Manaus is more productive than that of Manacapuru, and thus a better candidate for future attempts to establish a functional colony of this species.

The L. umbratilis populations of Manaus and Manacapuru differ consistently or significantly in their fecundity, fertility, adult longevity, and emergence. These differences may reflect some divergence of intrinsic biological features evolved as a result of their geographical isolation by the Rio Negro. Further investigations with these and other allopatric populations on either margin of the Negro-SolimõesAmazonas river system are planned or in progress. It is expected that multivariate analyses of the morphometry, cuticular hydrocarbon, and isoenzymes, as well as molecular and chromossomal analyses, and infection and cross-mating experiments will help reveal whether or not $L$. umbratilis has genetically diverged into two or more reproductively isolated populations of vectors or non-vectors of Leishmania guyanensis.
Acknowledgments - The authors wish to thank Mr. Raimundo Nonato L. Santos and Mr. Francisco L. Santos for technical assistance in the field, Mr. Rui A. de Freitas for identification of wild sand flies; Mr. Jansen F. de Medeiros and Mr. Pedro M. Amoedo for the statistical analyses; Mr. Walter S. Santos; and Mr. Ronildo B. Alencar for helping with the tables and figures. This work was financially supported by PPI/INPA 3060, PPGG7 847/95, and CNPq and Mr. Ronildo B. Alencar for helping with the tables and figures.

\section{REFERENCES}

ARIAS, J. R. \& FREITAS, R. A., 1977, On the vectors of cutaneous leishmaniasis in the central Amazon of Brazil. I. Preliminary Findings. Acta Amazonica, 7(2): 293-294.

ARIAS, J. R. \& FREITAS, R. A., 1978, Sobre os vetores da leishmaniose cutânea na Amazônia Central do Brasil. 2. Incidência de Flagelados em flebótomos selváticos. Acta Amazonica, 8: 387-396.

ARIAS, J. R. \& FREITAS, R. A., 1982, On the vectors of cutaneous leishmaniasis in the Central Amazon of Brazil. 3. Phlebotomine sand fly stratification in a terra firme forest. Acta Amazonica, 12(3): 599-608.

ARIAS, J. R. \& NAIFF, R. D., 1981, The principal reservoir host of cutaneous leishmaniasis in the urban area of Manaus, Central Amazon of Brazil. Mem. Inst. Oswaldo Cruz, 76(3): 279-286.

AZEVEDO, A. C., LAINSON, R., SOUZA, A. A., FE, N. F., FELICIANGELI, D. M., MENESES, C. R. \& RANGEL, E. F., 2002, Comparative studies of populations of Lutzomyia umbratilis (Diptera: Psychodidae) in Brazil and Venezuela. J. Med. Entomol., 39(4): 587-600.

BALBINO, V. Q., MARCONDES, C. B., ALEXANDER, B., LUNA, L. K. S., LUCENA, M. M. M., MENDES, A. C. S. \& ANDRADE, P. P., 2001, First report of Lutzomyia (Nyssomyia) umbratilis Ward \& Frahia, 1977 outside of Amazonian Region, in Recife, State of Pernambuco, Brazil (Diptera: Psychodidae: Phlebotominae). Mem. Inst. Oswaldo Cruz, 96(3): 315-317.

BARRETTO, M. P., 1942, Contribuição para o estudo da biologia dos flebótomos em condições experimentais. Tese de Doutorado, Faculdade de Medicina da Universidade de São Paulo, 162p.

BARRETT, T. V., 1993, Cutaneous leishmaniasis in Amazonas State, Brazil: Eco-epidemiology and questions of control. Proceedings of National Workshop Research and Control of Leishmaniasis in Brazil, pp. 31-44. Recife, 13-17/9.

ELNAIEM, D. E. A., WARD, R. D. \& REES, H. H., 1991, Chemical factors controlling oviposition of Lutzomyia longipalpis (Diptera: Psychodidae). Parassitologia, 33: 217-224.

ELNAIEM, D. A. \& WARD. R. D., 1992, The thigmotropic oviposition response of the sandfly Lutzomyia longipalpis (Diptera: Psychodidae) to crevices. Ann. Trop. Med. Parasitol., 86: 425-430.

FERRO, C., CÁRDENAS, E., CORREDOR, D., MORALES, A. \& MUNSTERMANN, L. E., 1998, Life cycle and fecundity analysis of Lutzomyia shannoni (Kyar) (Diptera: Psychodidae). Mem. Inst. Oswaldo Cruz, Rio de Janeiro, 93(2): 195-199. 
FORATTINI, O. P., 1973, Entomologia Médica, pp.121-135. In: O. P. Forattini, Subfamília Phlebotominae-Biologia, vol. 4, 658p., Edgard Bluncher, São Paulo.

FOWLER, J. \& COHEN, L., 1990, Practical statistics for field biology. Open University Press, pp. 166-178.

GENTILE, B., LE PONT, F., PAJOT, F. X. \& BESNARD, R., 1981, Dermal leishmaniasis in French Guiana: the sloth (Choloepus didactylus) as a reservoir host. Trans. Roy. Soc. Trop. Med. Hygiene, 75(4): 612-613.

KILLICK-KENDRICK, R., LEANEY, A. J. \& READY, P. D., 1977, The establishment, maintenance and productivity of a laboratory colony of Lutzomyia longipalpis (Diptera: Psychodidae). J. Med. Entomol., 13: 429-440.

KILLICK-KENDRICK, R., 1987, Methods for the study of phlebotomine sandflies, pp. 473-497. In: W. Peters \& R. Killick-Kendrick (eds.), The Leishmaniases in Biology and Medicine, vol. 1, 550p. Academic Press, London.

KILLICK-KENDRICK, M. \& KILLICK-KENDRICK, R., 1991, The initial establishment of sandfly colonies. Parassitologia, 33: 315-320.

LAINSON, R., WARD, R. D. \& SHAW, J. J., 1976, Cutaneous leishmaniasis in north Brazil: Lutzomyia anduzei as a major vector. Trans. Roy. Soc. Trop. Med. Hygiene, 70: 171-172.

LAINSON, R., SHAW, J. J., WARD, R. D., READY, P. D. \& NAIFF, R. D., 1979, Leishmaniasis in Brazil: XIII. Isolation of Leishmania from armadillos (Dasypus novemcinctus) and observations on the epidemiology of cutaneous leishmaniasis in north Pará State. Trans. Roy. Soc. Trop. Med. Hygiene, 73: 239-242.

LAINSON, R., SHAW, J. J. \& POVOA, M., 1981, The importance of edentates sloths and anteaters as primary reservoirs of Leishmania braziliensis guyanensis, causative agent of "Pian-bois" in Northern Brazil. Trans. Roy. Soc. Trop. Med. Hygiene, 75(4): 611-612.

LAWYER, P. G., ROWTON, E. D., PERKINS, P. V., JOHNSON, R. N. \& JOUNG, D. G., 1991, Recent advances in laboratory mass rearing of Phlebotomine sand flies. Parassitologia, 33: 361-364.

LE PONT, F. \& PAJOT, F. X., 1980, La leishmaniose em Guyane Française. 1. Étude de l'écologie et du taux d'infection naturelle de Lutzomyia (Nyssomyia) umbratilis Ward et Fraiha, 1977 em saison seche. Considérations épidémiologiques. Cahiers ORSTOM, Série Ent. Méd. et Parasitologie, 18: 359-382.
LE PONT, F., 1982, La leishmaniose em Guyane française, 2. Fluctuations saisonnières d'abondance et du taux d'infection naturelle de Lutzomyia (Nyssomyia) umbratilis Ward et Fraiha, 1977. Cahiers ORSTOM, Ent. Méd. et Parasitologie, vol.XX(4): 269-277.

NIEVES. E., 1997, Fatores físicos e biológicos na oviposição de Lutzomyia migonei (Diptera: psychodidae) em laboratório. MSc Thesis, UFMG, Belo Horizonte, MG, Brasil.

PAJOT, F. X., LE PONT, F., GENTILE, B. \& BESNARD, R., 1982, Epidemiology of leishmaniasis in French Guiana. Trans. Roy. Soc. Trop. Med. Hygiene, 76: 112-113.

QUEIROZ, R. G.,1995, Phlebotomine Sand flies of a leishmaniasis focus in Baturité, Brazil. PhD Thesis, Department of Biology, Imperial College of Science, Technology and Medicine, University of London, Ascot, UK.

READY, P. D., LAINSON, R., SHAW, J. J. \& WARD, R., 1986, The ecology of Lutzomyia umbratilis Ward \& Fraiha (Diptera: Psychodidae), the major vector to man of Leishmania brasiliensis guyanensis in north-eastern Amazonia Brazil. Bull. Ent. Res., 76: 21-40.

SHERLOCK, I. A. \& SHERLOCK, V. A., 1959, Criação e biologia, em laboratório, do "Phlebotomus longipalpis" Lutz \& Neiva, 1912. Rev. Bras. Biol., 19: 229-250.

WARD, R. D., 1977, The colonization of Lutzomyia flaviscutellata (Diptera: Psichodidae), a vector of Leishmania mexicana amazonensis in Brazil. J. Med. Entomol., 14(4): 469-476.

WARD, R. D. \& FRAIHA, H., 1977, Lutzomyia umbratilis, a new species of sand fly from Brazil (Diptera: Psychodidae). J. Med. Entomol., 14: 313-317.

YOUNG, D. G. \& DUNCAN, M. A., 1994, Guide to the identification and geographic distribution of Lutzomyia sand flies in Mexico, the West Indies, Central and South America (Diptera: Psychodidae). Associated Publishers, Gainesville, Florida, n. 54, 881p. 